\title{
To Shake the Hand of Happiness: Luiz Ruffato's Inferno Provisório
}

\author{
Marguerite Itamar Harrison \\ Smith College, mharriso@smith.edu
}

Follow this and additional works at: https://scholarworks.smith.edu/spp_facpubs

Part of the Spanish and Portuguese Language and Literature Commons

\section{Recommended Citation}

Harrison, Marguerite Itamar, "To Shake the Hand of Happiness: Luiz Ruffato’s Inferno Provisório" (2017). Spanish and Portuguese: Faculty Publications, Smith College, Northampton, MA.

https://scholarworks.smith.edu/spp_facpubs/3 


\section{To Shake the Hand of Happiness: Luiz Ruffato's Inferno Provisório By Marguerite Itamar Harrison}

To shake the hand of happiness, as Seu Sebastião's family does at the beginning of "O Ataque," is always a short-lived accomplishment in Luiz Ruffato's hellish world. In Inferno Provisório, the sense of marginality, of living life on the periphery, derives from the author's decision to register in panoramic, five-volume form a raw and heartrending history of the working class in Brazil in the second half of the twentieth century. Correspondingly, his narrative lens captures factory workers who strive for upward mobility and get entangled in consumerist cravings. Yet he also portrays the lowly lower classes, the truly down and out: the unemployed, the sick, the unstable, the suicidal, the insignificant, misfits living in makeshift quarters, those excluded, exploited and discarded by society. This essay addresses this extremely marginalized sector of the populace in Ruffato's Inferno Provisório. I focus in particular on several stories in its third segment, Vista parcial da noite, set in the 1960s and 70s during the Brazilian dictatorship.

Luiz Ruffato's attention to marginality paradoxically takes aim at the center, at that which is most sacrosanct in the stories Brazil tells about itself: the nation and the family. He uses fiction to point to Brazilian society's pervasive flaws, mostly by way of intimate vignettes of families on the outer fringes. In Marilena Chaui's "Comemorar?" from Brazil: Mito fundador e sociedade autoritária (89-95), she aptly draws correlations between Brazil's colonial framework and its post-colonial makeup as an authoritarian society, linking public and private spheres. In Chaui's mapping of Brazil's authoritarian

profile, she stresses an overall societal arc within which political totalitarianism manifests 
itself (90). Within what Chaui terms "social authoritarianism," inequalities abound, rooted in a colonial pattern of socioeconomic imbalance. With a landholding master in command through the privilege and power of racial, gender and class "superiority," "naturally" inferior beings such as women, blacks, indigenous peoples, and immigrants become unremittingly relegated to the role of servitude (92).

In similar fashion, Luiz Ruffato’s fiction addresses these same structural parallels in Brazil's society: its hierarchical, top-down sociopolitical composition and the economic ramifications that historically and unremittingly polarize the country into "haves" and "have-nots." Within the family, this draconian configuration forces the disenfranchised into desperate, dog-eat-dog situations that often reproduce the same oppressive model on an intimate scale. In Inferno Provisório, therefore, to fight for legitimacy or entitlement is an uphill battle that pits subaltern individuals - even family members or bosom buddies - against each other, in a cutthroat race for survival that often ends in defeat. Ruffato's work thus portrays alienated human beings, cut off from citizenship and lineage.

\section{VIOLENT MECHANISMS OF EXCLUSION}

In Chapter One of Citizenship and Crisis in Contemporary Brazilian Literature (23-71), scholar Leila Lehnen expertly examines Inferno Provisório in light of the quest for citizenship, or civic entitlement, many times seemingly within reach, yet rarely attainable. According to Lehnen, the stories in Vista parcial da noite (originally published by Record in 2006, and to which "O Ataque" belongs) point to an inequitable society that is incapable of incorporating a downtrodden class of individuals into its fold. 
Within the five-tome set (subsequently published by Companhia das Letras as a single volume in $2016^{1}$ ), Vista parcial da noite, set in the 1960s and 70s, contains elements of sociopolitical critique grounded in its timeframe. In other words, in keeping with Chaui's analysis, Ruffato's narrative thread in Vista parcial da noite registers a palpable undercurrent of oppression, stemming from several interrelated axes of power: political, of course, in its underlying representation of the dictatorship period, yet also economic, social and familial.

Leila Lehnen's analysis confirms these multiple layers of coexistent oppression or, in her words, "modalities of violence" (Lehnen 25), found within both "internal and external frameworks" (47). According to Lehnen, Ruffato’s work points to "violent mechanisms of exclusion that permeate the Brazilian social fabric" (25), which she probes by examining specific stories and characters (46-57). In like manner, for scholar Marcus Vinícius Ferreira de Oliveira, the individuals in Ruffato’s Inferno Provisório are held hostage (Oliveira 177) within a rotting social matrix ruled by a despotic system, under which they have little voice or chance, and zero control (182) over their basic social rights, economic status, lives and fate.

Luiz Ruffato is determined to draw the reader into this system of exclusion, in an effort to use literature to political ends. By representing his non-heroic characters with all their faults and virtues, and in fragmented form, Ruffato casts them in a non-

\footnotetext{
1 Originally published in 2006 as an autonomous volume, Vista parcial da noite was composed of eleven stories. In the 2016 one-volume set, reorganized and revised by the author, Vista parcial da noite consists of 10 stories (109-192). Three stories from Vista parcial have been moved to other volumes: "A homenagem" and "Estação das águas" have been moved to $O$ Mundo Inimigo whereas "Haveres" is now in the fourth book, renamed Um céu de adobo. Now included in Vista parcial da noite are two stories from other volumes: "O segredo," from Mamma, son tanto felice and "Jorge Pelado," from $O$ Mundo Inimigo. References in the text will be to the 2016 version.
} 
romanticized, humanizing light, "without the aesthetization of misery" (Lehnen 25). He insists on the reader's participation in the process of piecing together the disparate narratives and fragmented lives of these marginalized individuals. In other words, the reader is present and participates in assembling the collective, patchwork fabric of their bleak lives. It is a weaving process, as if first aiming to obtain recognition of this marginalized populace, and ultimately, suggesting the need for rebuilding a better, more equitable humankind, out of its ruins.

\section{AN OVERLAY OF HUMAN EXPERIENCES}

Out of this emphasis on what Leila Lehnen terms "landscapes of disrepair and despair" (23), Luiz Ruffato creates a remarkable form of narrative bricolage (Lehnen 28). Within a collection of stories such as Vista parcial da noite, his innovative method is to construct a polyvalent and malleable structure that simulates a three-dimensional art installation, in its capacity to present multiple angles, actions, accents and attributes. ${ }^{2}$ As the title suggests, there is no single, omnipresent bird's-eye viewpoint. Each narrative manifests itself by way of fragmentation, suggesting that the lives of its characters are remnants, vestiges of what they once were or could become. There is a pervasive sense of incompleteness in these broken shards, these traces of lives. And, on a structural level, it is this very fragmentation upon which the author relies to gain the reader's empathy and collaboration in piecing the characters' narratives together.

Similarly, the volume as a whole presents itself with a purposeful lack of clear conclusivity, or even linear sequencing: the stories exist as loosely correlated chapters,

\footnotetext{
2 In his essay "O discurso sobre a precariedade," José Leonardo Tonus describes Luiz Ruffato's Eles eram muitos cavalos as an "installation book," applicable here as well.
} 
connected intertextually to other narratives in other volumes. Much like in Ruffato's signature book Eles eram muitos cavalos, set within the urban grit and grid of São Paulo, ${ }^{3}$ the overall composition of Vista parcial da noite consists of an overlay of human experiences. Even the typography Ruffato implements to register these life experiences shifts, through changes in font, typeface and punctuation, corresponding to variations of time, utterance and timbre.

This malleable inventiveness of form and content gives Luiz Ruffato's work a quality of macro interrelatedness or correspondence of broad scope, if you will, even as it zeroes in on the micro minuteness of artless souls and their personal tribulations. In this manner, Ruffato's narratives render a far-reaching mosaic of Brazil—and of humanity at large on a universal scale — at the same time that he holds tight to his mineiro origins by representing human beings whose lives are particular to rural-turned-industrial Southeast Brazil, to Minas Gerais, to Cataguases, to the suburban neighborhood of Paraíso, to the Beco do Zé Pinto, or to the banks of the Rio Pomba. In this vein, it is telling that in Tecido em ruínas, Marcus de Oliveira fittingly examines the interstitial bonds between autobiography and fiction in Ruffato's portrayal of his native Cataguases. In fact, within Oliveira's thorough analysis of Cataguases as real and imaginary in Ruffato's literary world, the fictional Cataguases stands in as a cross-section or microcosm of Brazil's complex path to modernization (76).

\section{BETWEEN OSTRACISM AND DESOLATION}

\footnotetext{
${ }^{3}$ For in-depth critical analysis of Luiz Ruffato's Eles eram muitos cavalos by fifteen international scholars, see Uma cidade em camadas: Ensaios sobre o romance Eles eram muitos cavalos.
} 
With Luiz Ruffato's sense of marginality in mind, it is worth pondering the meaning given to Inferno Provisório's title, which, on the one hand, might merit a positive interpretation, based on hell being granted temporary or provisional status. On the other hand, a more negative outlook could be argued, based on the fact that most of the individuals represented in Inferno Provisório are unable to opt for a permanent version of hell, which would presuppose death. Rather, they literally inhabit a jerry-built, living hell, with little or no entitlements. In other words, they live in self-defeating quicksand, on an ever-shifting ground that provides transitory hope-against-hope and moments of sweet tenderness, amidst the pervasiveness of fierce violence and crushing tragedy. The character of Bibica is a telling example, whose trajectory is told piecemeal in multiple narratives spanning several of Inferno Provisório's clearly delineated segments. As a single mother who has had to precariously sustain her family through prostitution, she suffers the devastating loss of two young sons: Marquinho is run over by a truck and Jorge Pelado is taken away and imprisoned for a petty crime. Her third son, Zunga, becomes a drunkard who wanders aimlessly in a state of delirium. Bibica herself is one of several Ruffato characters who reaches her lamentable end in an asylum for the insane.

The temporary quality Ruffato registers in the title might indeed signal the deciding role our individual behavior plays in our own destinies. What we accomplish, good or bad, conditions life's course. Nevertheless, for Brazil's underbelly of "havenots," daily life is an unrelenting and agonizing form of Russian roulette. Under society's dominion, they are positioned in the rotation closest to that single bullet. In such closerange proximity to tragedy, life is gravely spent in the line of sure fire, between ostracism 
and desolation. Impoverishment, alcoholism, domestic violence, prostitution, child labor, inner turmoil, eviction, abandonment, paranoia, disease and trauma are some of the afflictions Ruffato's characters immutably endure.

It is thus not surprising that Luiz Ruffato's Vista parcial da noite is cast in a somber tone, repeatedly marked by night's darkness—and understatedly evoking the oppressive mark of the dictatorship — evident at the outset from its title. ${ }^{4}$ The ten narratives included in the revised 2016 volume portray broken families, beset by agony and disintegration, discrimination and anguish, violence and loss. According to Marcus de Oliveira in Tecido em ruínas, Ruffato has a narrative penchant for recurring themes, which include bitter memories, impoverished lives, remorse, doomed relationships and drunkenness, among others (Oliveira 178). In his review titled "Vista parcial da vida," Luiz Carlos Monteiro reiterates these same themes present in Vista parcial da noite: perpetual poverty, grueling labor, insecurity, life struggles without respite or reprieve, and collective wretchedness (Monteiro 30). Ruffato's fictional world is thus shaped by these thematic patterns of extreme impoverishment, repression, and exclusion.

\section{DUTIFUL SONS, DESPERATE PARENTS AND A DESTRUCTIVE SYSTEM}

According to Marcus de Oliveira, Vista parcial da noite depicts frequent tensions between individuals and authority figures (Oliveira 184). In "Inimigos no quintal" and "O Ataque," for instance, the presence of authority is magnified, in order for Luiz Ruffato's fiction to draw subtle (even subliminal) parallels to the totalitarian regime. A sense of

\footnotetext{
4 In a 2008 BRASA conference presentation entitled "'E os outros habitantes das trevas': Vistas parciais do panorama social brasileiro no Inferno Provisório de Luiz Ruffato" I focused on this somber palette, which served as the inspiration for this essay.
} 
surveillance, censure and attack on the one hand, and of covertness, dread and paranoia on the other, permeate these episodes, casting the characters in a vulnerable Us versus almighty Them faceoff.

In terms of the medical establishment and the law, stories such as "O Morto" and "Jorge Pelado" demonstrate the unequivocal upper hand allotted to medical doctors, law enforcement and civic officials over the unjust treatment of marginalized individuals. Ruthless characters - such as Doutor Delegado Bacharel Aníbal Resendes from “O Morto" and Doutor Normando from "Jorge Pelado"—rule with resolute rigidity and impunity. For instance, in "Jorge Pelado," a model boy's theft of a soccer ball is judged as an extreme crime, worthy of extended incarceration and perpetual exile from home and family.

Under political or societal authority, low-income family members are commonly subjected to ill treatment and injustice. As an adult, Miguel, from "Cicatrizes," is made figuratively impotent by the system, going from his role as a hardworking breadwinner, father of eight to being duped into losing his steady odd-job status, and subsequently his good health. Shut out from regular employment and standard housing, Miguel must settle for a cobbled-together existence, born out of improvisation. He relies on skills he learned as a youth having to grow up too fast when his own father died prematurely and his mother disappeared. He and his siblings were then dispersed, embarking on lone, makeshift lives of their own, as direct victims of their family's disintegration.

In essence, in Inferno Provisório as a whole, Luiz Ruffato repeatedly targets the family as a focus for his outspoken commentary on Brazil's social biases and inequities. At times, as seen above, the establishment is defective and discriminatory, making low- 
income families its principal casualties. At other times, the family nucleus mirrors society's malfunctions and disparities. In addition to female characters that are victims of domestic violence, mental illness, and subordination, ${ }^{5}$ Ruffato frequently portrays father and son interactions as an intimate way of expressing how patriarchal power can be damaging and destructive to the powerless.

From Vista parcial da noite, two stories in particular capture this tension and imbalance: "Aquele Natal inesquecível" and "O profundo silêncio das manhãs de domingo." In each of them, the father figure plays an active, decisive role, with brutal aftereffects. Likewise, the sons are portrayed as dutiful schoolchildren and/or diligent trainees in the workplace.

Although the father is absent from the plot scene in "Aquele Natal inesquecível," his iron-fisted behavior nonetheless subjects family members to violent and emotional consequences. Set on Christmas Eve, the storyline contrasts a benevolent shop-owner named Seu Boi with a nameless, drunken and abusive father. Through young son Nando, the reader is witness to the heartless harm his father inflicts on his mother and siblings, within the sanctity of their home. At the end of the story, what should have represented a rare moment of seasonal joy and recompense for Nando — when he gets to open his small Christmas gift from Seu Boi-becomes subsumed into feelings of rage and torment. Moreover, the nifty multifunctional tool—the Swiss-army knife—that Nando receives from Seu Boi turns into a weapon suggestive of potential violence. A brief instance in

\footnotetext{
${ }^{5}$ In his introductory speech at the 2012 Frankfurt Book Fair, Luiz Ruffato made reference to Brazil as a "male chauvinist" country rife with domestic violence and abuse toward women, children and adolescents, among other misfortunes (Nielson 93). In Ruffato's concluding remarks, he faults Brazilians for "turning [their] backs on the other-whether immigrant, poor, black, indigenous, female, homosexual" [...] (95).
} 
which to "shake the hand of happiness" is a shattered dream, turned nightmare, as anticipated aggression filters down from father to son.

In "O profundo silêncio das manhãs de domingo," the father figure is front and center as the story's key player. Baiano's drastic actions toward his only male offspring, his pride and joy—eight-year-old Cláudio—are equally devastating, and, moreover, deadly. Part of the episode's disorienting factor for the reader exists in the overlapping of past experiences and childhoods that are conveyed through Ruffato's experimental style. Through complex storytelling, Baiano's own childhood, dominated by his father's cruel exploits, contrasts with the kind-hearted treatment he displays toward his own son.

For the first part of the story, the reader marvels at the fact that Baiano's behavior eschews the tyrannical, patriarchal model. He is hailed as a hero for saving individuals from drowning in the river. Yet Baiano's refusal to obey a boss and, thus, hold a steady job keeps him at the bottom of the social totem pole, unable to sustain his family. Suddenly trapped in a dolefully precarious life as a single parent of multiple children after his wife vanishes, Baiano begins to unravel from the inside out. This personal breakdown signals his family's dismantling.

Up to this point Baiano's son Cláudio trusts his father implicitly, following him to the riverbank on a tranquil Sunday morning, and even obeying orders to enter the cold waters. Tranquility swiftly turns to turbulence, and Ruffato's inventive placement of words on a page — contrasting vertical and horizontal text to signal action ("submergiu") and voice ("Pai!) respectively—reflects this disquieting change in mood and tone. Unable to grasp his father's intentions, Cláudio calls out to his father as he repeatedly comes up to the river's surface, gasping for air. With growing horror, readers come to the shocking 
realization that they have been key witnesses to Cláudio's murder and, subsequently, to Baiano's suicide. This tragic end proposes that the only way to escape the downward spiraling and noxious effects of a temporary, living hell is through death. Death represents deliverance, set within the resounding silence summoned by the story's title.

\section{TO BETTER THE ODDS}

In one of the bleakest stories in Vista parcial da noite, "Vicente Cambota," the reader bears witness to total disintegration and collapse, evident from the start. Vicente's father is a blank space on his birth certificate. His mother is a mentally disturbed woman who eventually sets fire to the neighborhood and is taken away for good. Zé Pinto takes in the orphaned Vicente, giving him a place to live and purposeful tasks. For a short while he manages to work and do simple deeds while interacting with others, before being undone by drink, gambling, disease and decay. Derelict, Vicente ultimately becomes the community's pariah, scorned and discarded by society.

To rescue or redeem individuals like Vicente may not necessarily be possible. Yet by casting the minuteness of his battered underdog existence within the magnifying scope of an ailing, faulty and inhumane society entrenched in what Marilena Chaui has termed a structurally hierarchical and authoritarian value system (89), Luiz Ruffato seeks a broader, more active redemption through the empathetic, big-hearted eyes of readers. The author's radical experiment—and achievement—is to generate reader empathy through the engine of form and structure: by shattering the mirror of his narratives (narratives which in turn mirror the analogous, authoritarian society in which they're embedded), we readers are not only drawn into characters' lives as we try to piece the shards together, 
but inescapably glimpse our own reflections in so doing. We thus reconstruct these "othered" others and see ourselves in the process.

In other words, by portraying the shattered lives of a marginalized population in Inferno Provisório that fights against all odds for survival and validation, and, moreover, by making more evident through narrative splintering the flaws of a society that is brutally prejudiced, intolerant, and inequitable, Ruffato spurs us, at the very least, to aim towards justice, to better the odds. We behold grit and tenacity, even as we find ourselves flailing to piece together these ramshackle lives in an atmosphere of indisputable defeat, fracture and ruin. By doing so, we are propelled forward, to reassemble and rebuild through humanizing means: to make shaking the hand of happiness an enduring act.

\section{Smith College}

\section{WORKS CITED}

Chaui, Marilena. Brasil: Mito fundador e sociedade autoritária. $5^{\text {th }}$ ed. São Paulo: Fundação Perseu Abramo, 2004 (1st ed. 2000).

Uma cidade em camadas: Ensaios sobre o romance Eles eram muitos cavalos. Edited by Marguerite Itamar Harrison. Vinhedo, São Paulo: Editora Horizonte, 2007.

Lehnen, Leila. Citizenship and Crisis in Contemporary Brazilian Literature. New York: Palgrave Macmillan, 2013.

Monteiro, Luiz Carlos. "Vista parcial da vida.” Revista Continente 74, Feb.2007, pp. 3031. www.revistacontinente.com.br

Nielson, Rex P. “Dispatch from Brazil.” Mester 42: 1, 2013, pp. 91-95. http://escholarship.org/uc/item/2j443663

Oliveira, Marcos Vinícius Ferreira de. Tecido em ruínas: Fabricação e corrosão das Cataguases no Inferno provisório de Luiz Ruffato. São Paulo: Intermeios, 2013.

Ruffato, Luiz. Eles eram muitos cavalos. $11^{\text {th }}$ edition. São Paulo: Companhia das Letras, 
2013.

---. Inferno provisório. 1st. ed. São Paulo: Companhia das Letras, 2016.

---. Vista parcial da noite. Rio de Janeiro: Record, 2006.

Tonus, José Leonardo. "O discurso sobre a precariedade em Luiz Ruffato e Arlindo

Gonçalves." Estudos de Literatura Brasileira Contemporanea, 41, Jan./Jun. 2013, pp. 47-59. 